\title{
Making of a CEO: Study of the successful CEO'S globally who and what are CEO'S
}

\author{
Dr. Esha Jain ${ }^{1}$, Ashank Yadav ${ }^{2}$ \\ ${ }^{1,2}$ GD Goenka University, Gurgaon, India
}

\begin{abstract}
The purpose of the study is to understand that what are the key elements which make up a successful CEO of an organization who is able to contribute to the growth and development of an organization. The study is focused on understanding the structure of the top level of an organization and placing the position of a CEO in it. By placing CEO on the top in the organizational hierarchy, understanding his/her roles and skills. Taking the examples of the best and the worst CEO'S to get a clear view of what is required to become a successful CEO.

Keywords: organization, Chief Executive Officer, hierarchy, development.
\end{abstract}

\section{Objectives of The Study}

- To know what is the top level management in an organization and who are the people of which it consists.

- To know various positions of the policy and strategy formulators in an organization and where do they fill it.

- To know the job description of top level employees in brief and understanding the level of the CEO in an organization.

- To deeply know who a CEO is and what are the essential and required skills he/she should possess along with their roles and responsibilities.

- To take examples to clearly know what made the best and the worst CEO'S of the world during this decade to fulfill the main objective of the study.

\section{Research Methodology}

The method to conduct this research had been to mine out the data from trusted sources and compile and understand that data by creating additions into it. The research is done by understanding what top level management in an organization is and what is the role it plays in an organization. Secondly what are the positions in top level management and what is the work done by them. Then where does the CEO fall in the hierarchy of an organization and who are the other fellow chief operating officers and what are their roles and responsibilities and how they are different from those of a CEO. Moving ahead the research involves understanding who a CEO actually is and how their roles, goals and responsibilities changes from organization to organization. Broadly discussing what are the specific skills, roles and responsibilities of a CEO in an organization. Studying the examples of the best as well as the worst CEO'S to get the picture clear so as to find out the significance and importance of a good CEO and what is takes to be one.

\section{Introduction}

There are several position in the top level of an organization. Top-level managers play a major role in the mobilization of outside resources. They are accountable to the shareholders and general public, and they are also responsible for framing policies for the business. Significant business decisions are made at this level. In general, this level of management is concerned with administrative functions that affect all aspects of the organization. Top management also translates the policy formulated by the board-of-directors into goals, objectives, and strategies, and projects a shared-vision of the future. It makes decisions that affect everyone in the organization, and is held entirely responsible for the success or failure of the enterprise. Usually in the hierarchy the senior most manger is known as the chief executive officer. But there are several other positions also which are included in the top level management.

- Chairman/Chairwoman/Chair: typically leads the company's board of directors and chairs board meetings. The chairman may either be a full-time member of the company's executive management team with responsibility for day-to-day operations or a non-executive chairman who is independent of the company's management.

- Chief Executive Officer: today, the chief executive officer is typically the highest ranking executive officer with full responsibility for the activities of the company, including long-term strategy and day-to- 
day operations. In most instances, the chief executive officer has apparent authority to bind the corporation, even when acting without express authority from the board of directors.

- President: if a company does not have a chief executive officer, the president will be the highest ranking executive officer. If there is a chief executive officer, the president will typically focus on day-to-day operations.

- Managing Director: a common title in European companies, the managing director has a role similar to a chief executive officer.

- General Manager: historically, a general manager had more authority than a president and could act without specific board authority. Today, the title describes an officer with responsibility for managing both income and expenses.

Under the classification of chief officer's category there are other top level managers as well who are responsible for different departments and functions of an organization. Major posts which are present generally in most of the organization.

- Chief Operating Officer (COO) - The COO is often referred to as the senior vice president, as the scope of the role encompasses most (if not all) aspects of a given organization's operations. These include sales, logistics, distribution, and other day-to-day activities central to organizational success.

- Chief Financial Officer (CFO) - Simply put, the CFO monitors and interprets company-wide financials and focuses on the profitability and cost incursions of all departments.

- Chief Information Officer (CIO) - Sometimes referred to as the CTO (Chief Technology Officer), the CIO takes a top-down view of the technological integration of company operations and the flow of communication. This is much more vital to organizational success today than in the past and will continue to grow as a central concern for organizations.

- Chief Marketing Officer (CMO) - The CMO considers branding messages, advertising strategies, public relations, and a wide variety of other communications-based aspects of the business. He or she looks carefully at how the organization is perceived and what the average consumer wants and expects.

\section{Who Is A CEO}

The CEO (Chief Executive Officer), refers to the head of an organization as in the person who presides over or is in charge of an organization. The Chief Executive Officer (CEO) is the highest ranking executive manager in a corporation or organization. The CEO has specific responsibilities depending on the needs of his or her organization. The job description of a CEO varies by organization. The main responsibilities include developing and implementing high-level strategies, making major corporate decisions, managing the overall operations and resources of a company, and acting as the main point of communication between the board of directors and the corporate operations. The CEO will often have a position on the board, and in some cases is even the chair.

The CEO reports to the Board of Directors or in some nonprofit settings, such as state government, the CEO may be the head of an agency or department and report to the office of the governor. The CEO may also own the business, and may have founded the business, so his or her commitment to the business is significant. In these cases, a Board of Directors may exist, but its authority is nominal and advisory.

There are various other titles for the position of CEO including president and executive or managing director. The role of the CEO will vary from one company to another depending on its size and organization. In smaller companies, the CEO will often have a much more hands-on role in the company, making a lot of the business decisions, even lower-level ones such as the hiring of staff. However, in larger companies, the CEO will often deal with only the higher-level strategy of the company and directing its overall growth, with most other tasks delegated to managers and departments.

\section{Roles And Responsibilities Of A CEO}

The CEO has overall responsibility for creating, planning, implementing, and integrating the strategic direction of an organization. This includes responsibility for all components and departments of a business. The CEO makes certain that the organization's leadership maintains constant awareness of both the external and internal competitive landscape, opportunities for expansion, customers, markets, new industry developments and standards, and so forth.

The CEO is responsible for the success or failure of the company. Operations, marketing, strategy, financing, creation of company culture, human resources, hiring, firing, compliance with safety regulations, sales and personal relations. This all falls on the CEO's shoulders. The CEO's duties are what she actually does, the responsibilities she doesn't delegate. Some things can't be delegated. Creating culture, building the senior management team, financing road shows, and, indeed, the delegation itself can be done only by the CEO. 
There are many responsibilities on the head of the CEO which could be classified major points-

- Leading, guiding, directing, and evaluating the work of other executive leaders including presidents, vice presidents, and directors, depending on the organization's reporting structure.

- Effectively managing the human resources of the organization according to authorized personnel policies and procedures that fully conform to current laws and regulations.

- Soliciting advice and guidance, when appropriate, from a Board of Directors. Also supports operations and administration of Board by advising and informing Board members, interfacing between Board and staff, and supporting Board's evaluation of chief executive.

- Formulating and implementing the strategic plan that guides the direction of the business or organization as well as overseeing design, marketing, promotion, delivery and quality of programs, products and services.

- Overseeing the complete operation of an organization in accordance with the direction established in the strategic plans and evaluating the success of the organization.

- Fundraising planning and implementation, including identifying resource requirements, researching funding sources, establishing strategies to approach funders, submitting proposals and administrating fundraising records and documentation

- Maintaining awareness of both the external and internal competitive landscape, opportunities for expansion, customers, markets, new industry developments and standards, and so forth.

- Representing the organization for civic and professional association responsibilities and activities in the local community, the state, and at the national level.

- Recommends yearly budget for Board approval and prudently manages organization's resources within those budget guidelines according to current laws and regulations.

- Demonstrating the leadership necessary to make the organization's mission a success. This leadership includes providing leadership vision, leadership that attracts followers, and all other aspects of successful leadership.

The CEO's day-to-day duties may depend on the size of the company he or she oversees. In a big company, setting the strategy in all departments and for all facets of the industry can be a full-time job. This is why you never see CEOs of large corporations stepping into the warehouse and helping to get orders through. In smaller companies and start-ups, things are usually different. A CEO who was also the founder of the company and is struggling to make it grow probably has a more hands-on role. He or she is more likely to step into any role necessary to get the job done. And, of course, the daily responsibilities of a CEO may also vary across industries. Even though they can delegate power, CEOs are ultimately responsible for everything related to management, such as operations and financial matters. This means that the chief operating officer (COO) and chief financial officer (CFO) report directly to the CEO. Since the board of directors chooses the CEO, the CEO must, in turn, report to the board.

Depending on how involved the board chooses to be, it can take a backseat to the CEO's vision and decisions. Or, the board could opt to take a more direct role and charge the CEO with carrying out its plans. The CEO's personality is a major factor in determining his or her relationship with the board. In general, CEOs tend to have domineering, arresting personalities that can help them wield power over a board. But because the board has the power to choose and remove the CEO, there's always that check on power that can reign in a CEO's behavior.

Being a good CEO is about far more than just investment performance. Leading a company and creating value depend on many skills that are hard to measure that is strategic vision, authenticity, long-term planning. And investors certainly aren't the only stakeholders that need tending to; the best-run companies connect effectively with customers, employees, and the communities where they operate.

\section{Examples of the most successful CEO'S worldwide-}

\section{Jeff Bezos}

(Rank \#1 by HBR and Forbs)

Under leadership of Jeff Bezos, Amazon continues to push toward the next new thing. Based on market cap, the online retailer is the second-largest e-commerce company in the world and continues to strengthen its position globally. In September 2014, Bezos announced that Amazon would be plugging \$2 billion of investment into India, a hotly-contested emerging market that some see as the next frontier for web retail. While analysts worry that he is spreading the company too thin--Amazon in the last year has announced projects including delivery drones, its first smart phone and a television set-top box to stream media content-Bezos remains dedicated to investing cash from operations into new endeavors that he thinks will strengthen the Amazon ecosystem. The Seattle firm, which celebrated its 20th anniversary in July, continues to grow and revenue is forecasted to hit $\$ 90$ billion this year, a $22 \%$ increase. Bezos still owns $18 \%$ of Amazon, which he founded in 1994. 


\section{Larry Ellison}

(Rank \#2 by HBR and Forbs)

Larry Ellison shocked the business world this September when he announced plans to step down as Oracle's CEO. After having built databases for the CIA, Ellison founded Oracle in 1977 and has never left. He will remain Chief Technology Officer. An adrenaline junkie, he was arguably the first Silicon Valley hotshot to live large and very, very fast. After having suffered intense mountain biking and bodysurfing accidents, Ellison turned to sailing, where he's the main backer of America's Cup winner Oracle Team USA. In recent years, he's been buying up properties on the Hawaiian island of Lanai, which he bought for a reported $\$ 300$ million in 2012. He is said to own every hotel room on the island. His daughter Megan Ellison has found success as a film producer, having founded Annapurna Pictures, which was behind hits like Zero Dark Thirty and American Hustle. Ellison never met his biological father and was raised in a middle-class Chicago home by his great-aunt.

\section{Timothy Cook}

(Rank \#3 by HBR and Forbs)

Tim Cook is the man behind the most valuable company in the world Apple corporation, \$118 billion brand value and varsity player in design, technology, publishing, Hollywood and music. In May the company picked up Beats, the headphone and streaming music service, for $\$ 3$ billion. The opening weekend for the iPhone 6 in September set a new Apple record, selling 10 million smartphones in just three days.

\section{Mark Zuckerberg}

(Rank \#4 by HBR and Forbs)

Facebook CEO and founder Mark Zuckerberg bet big this year 2014 on new acquisitions, positioning his social network to ride the next hot trend. After secret meetings, Zuckerberg sealed a deal in February for Facebook to buy mobile messaging app WhatsApp for a staggering $\$ 19$ billion in cash and stock, shocking the tech world. The following month it spent \$2 billion on virtual reality headset maker Oculus VR, before it even had a product ready to sell. Facebook stock has soared, adding $\$ 15$ billion to Zuckerberg's net worth over the past year and making him the biggest dollar gainer on the FORBES 400. Facebook's 1.35 billion users make up $19 \%$ of the world's population. The company has a footprint in 25 countries, and the site is available in more than 70 languages. In October 2014, Zuckerberg visited China, where Facebook is banned, wowing admirers there by speaking in fluent Chinese.

\section{Larry Page}

(Rank \#5 by HBR and Forbs)

Running the most influential company of the digital era. Google still dominates online search, with a $65 \%$ share of the global market. There are now more than a billion active Android devices, one for every seven people. CEO Larry Page oversaw a string of acquisitions in the past year, including programmable home thermostat maker Nest for $\$ 3.2$ billion. In October, he transferred most of his daily responsibilities to Sundar Pichai so he could focus on longer-term strategy. Cofounder Brin runs Google X, the secretive division of the search engine company that focuses on risky projects, such as self-driving cars, smart contact lenses, airborne wind turbines and Google Glass. In April Google issued a stock split that helped consolidate the voting power of Page, Brin and other executives. The company has 40,000 employees in 40 countries.

\section{Examples of the worst CEO'S which lead the organization to shrinking and crippling-} Steve Ballmer

In 2013 Steve Ballmer resigned as CEO of Microsoft. After being replaced, within a year he resigned as a Board member. Both events triggered analyst enthusiasm, and the stock rose. However, Mr. Ballmer left Microsoft in far worse condition after his decade of leadership. Microsoft missed the market shift to mobile, over-investing in Windows 8 to shore up PC sales and buying Nokia at a premium to try and catch the market. Unfortunately Windows 8 has not been a success, especially in mobile where it has less than $5 \%$ share. Surface tablets were written down, and now console sales are declining as gamers go mobile. As a result the new CEO has been forced to make layoffs in all divisions most substantially in the mobile handset (formerly Nokia) business. Job growth appears highly unlikely at Microsoft. Weakening positions in all markets portends more layoffs for the once formidable market leader.

\section{Ed Lampert}

By nine straight quarterly losses. Since the 5/2012 column the CEO has shuttered several stores, and sales continue dropping at those that remain open. Industry pundits now call Sears irrelevant, and the question is looming whether it will follow Radio Shack into oblivion soon. CEO Lampert has singlehandedly destroyed the Sears brand, as well as that of its namesake products such as Kenmore and Diehard. He has laid off 
thousands of employees as he consolidated stores, yet he has been unable to capture any value from the unused real estate. Meanwhile, the leadership team has been the quintessential example of "a revolving door at headquarters." From about \$50/share 5/2012 (well off the peak of $\$ 190$ in 2007,) the stock has dropped to the mid-\$30s which is about where it was in its first year of Lampert's leadership (2004.)

\section{Mike Duke}

Mr. Duke has left Wal-Mart, but not in great shape. Since 2012 the company has been rocked by scandals, as it came to light the company was most likely bribing government officials in Mexico. Meanwhile, it has failed to defend its work practices at the National Labor Relations Board, and remains embattled regarding alleged discrimination of female employees. The company's employment practices are regularly the target of unions and those supporting a higher minimum wage. The company has had 6 consecutive quarters of declining traffic, as sales per store continue to lag - demonstrating leadership's inability to excite people to shop in their stores as growth shifts to dollar stores. The stock was $\$ 70$ in 2012 , and is now only $\$ 75.60$, even though the S\&P 500 is up about 50\%. So far smaller format city stores have not generated much attention, and the company remains far behind leader Amazon in on-line sales. WalMart increasingly looks like a giant trapped in its historical house, which is rapidly dilapidating.

\section{Jeff Immelt}

When CEO Immelt took over for Jack Welch he had some tough shoes to fill. Jack Welch's tenure marked an explosion in value creation for the last remaining original Dow Jones Industrial's component company. Revenues had grown every year, usually in double digits. Profits soared, employment grew tremendously and both suppliers and investors gained as the company grew. But that all stalled under Immelt. GE has failed to develop even one large new market, or position itself as the kind of leading company it was under Welch. Revenues exceeded \$150B in 2009 and 2010, yet have declined since. In 2013 revenues dropped to $\$ 142 \mathrm{~B}$ from $\$ 145 \mathrm{~B}$ in 2012 . To maintain revenues the company has been forced to continue selling businesses and downsizing employees every year. Total employment in 2014 is now less than in 2012. Yet, Mr. Immelt continues to keep his job, even though the stock has been a laggard. From the near $\$ 60$ it peaked at his arrival, the stock faltered. It regained to $\$ 40$ in 2007 , only to plunge to under $\$ 10$ as the CEO's over-reliance on financial services nearly bankrupted the once great manufacturing company in 2009. As the company ponders selling its long-standing trademark appliance business, the stock is still less than half its 2007 value, and under $1 / 3$ its all-time high.

\section{John Chambers}

In 2012 it was clear that the market shift to public networks and cloud computing was forever changing the use of the network equipment which had made Cisco a modern growth story under long-term CEO Chambers. Yet, since that time there has been no clear improvement in Cisco's fortunes. Despite 2 controversial reorganizations, and 3 rounds of layoffs, Cisco is no better positioned today to grow than it was before. Increasingly, CEO Chambers' reorganizations and layoffs look like so many machinations to preserve the company's legacy rather than a clear vision of where the company will grow next. Employee morale has declined, sales growth has lagged and although the stock has rebounded from 2012 lows, it is still at least 10\% short of 2010 highs even as the S\&P hits record highs. While his tenure began with a tremendous growth story, today Cisco is at the doorstep of losing relevancy as excitement turns to cloud service providers like Amazon. And the decline in jobs at Cisco is another sign of the need for new leadership.

\section{Conclusion}

To become a good CEO or rather the best, there are some very specific elementary skills inhabited by the company chief. Although well-educated, experienced and talented leaders are able to climb the corporate ladder by possessing things which others lack. These skills are variedly classified as delegating work, foreseeing and predicting the market future, efficiently planning and executing, being an extrovert, making a correct move on correct time, maintain the balance between the shareholders, employees and the customers, formulating best strategies and polices and carrying them to the employee groups efficiently, constantly innovating and developing. By finding about the corporation health and growth or decline we get a correct estimate of hoe the CEO has performed. The accountability of a CEO is very high, in fact the highest in an organization. In most of the cases he/she is solely responsible for the profits or losses the corporation makes. They could be largely criticized for not meeting the expectations of the shareholders and the stakeholders of the corporation. It is generally noted that the highest remunerated CEO is usually well performing, apart from the fact that CEO'S of the US are comparatively paid more than in any other country. By the examples included in the study it is clearly understood that what are the key elements which make the best CEO'S the best and the worst CEO'S worst. This clearly helps to see the picture of how even big organizations can go crippling in a short span of time losing market share, profits, investor's faith and assets. Being a CEO is clearly a job of heavy responsibility and is needed to be performed with numerous skills as the roles expands. 


\section{References}

[1] Retrieved 12 Apr. 2017 from http://www.investopedia.com/terms/c/ceo.asp

[2] Retrieved 30 Apr. 2017 from http://humanresources.about.com/od/glossaryc/g/ceo_title.htm

[3] "Top-Level Management." Boundless Management. Boundless, 08 Dec. 2014. Retrieved 15 Dec. 2014 from https://www.boundless.com/management/textbooks/boundless-management-textbook/introduction-to-management-1/managementlevels-and-types-18/top-level-management-118-7570/

[4] Retrieved 19 Mar. 2016 from http://www.businessdictionary.com/definition/top-management.html

[5] Retrieved 11 Mar. 2016 from http://www.insideindianabusiness.com/contributors.asp?id=987

[6] Retrieved 15 Apr. 2017 from http://managementhelp.org/chiefexecutives/job-description.htm

[7] Retrieved 11 Mar. 2016 from http://humanresources.about.com/od/job-titles/f/Chief-Executive-Officer-Ceo-Do.htm

[8] Retrieved 26 Apr. 2017 from http://www.steverrobbins.com/articles/ceojob/

[9] Retrieved 12 Apr. 2017 from http://money.howstuffworks.com/ceo1.htm

[10] Retrieved 11 Mar. 2016 from http://managementhelp.org/chiefexecutives/job-description.htm

[11] Retrieved 09 Apr. 2017 from http://www.forbes.com/sites/mikalbelicove/2013/09/12/the-best-performing-ceos-in-the-worldinfographic/

[12] Retrieved 15 Mar. 2016 from http://www.businessinsider.in/6-Daily-Habits-Of-The-Worlds-Most-Successful CEOs/articleshow/44775222.cms

[13] Retrieved 10 Apr. 2017 from https://hbr.org/2014/11/the-best-performing-ceos-in-the-world

[14] Retrieved 29 Jun. 2015 from http://www.forbes.com/sites/adamhartung/2014/08/29/5-worst-ceos-revisited-job-creators-or-killersthis-labor-day/2/

[15] Retrieved 27 Mar. 2016 from www.forbes.com/profile/jeff-bezos/

[16] Retrieved 15 Apr. 2017 from http://www.forbes.com/profile/larry-ellison/

[17] Retrieved 26 Mar. 2016 from http://www.forbes.com/profile/mark-zuckerberg/

[18] Retrieved 22 Mar. 2016 from http://www.forbes.com/lists/2011/12/ceo-compensation-11_John-T-Chambers_736O.html

[19] Retrieved 19 Apr. 2017 from http://www.forbes.com/profile/larry-page/

[20] Retrieved 17 Apr. 2017 from http://www.forbes.com/sites/adamhartung/2014/08/29/5-worst-ceos-revisited-job-creators-or-killersthis-labor-day/

[21] Retrieved 24 Mar. 2016 from http://247wallst.com/special-report/2014/04/04/nine-ceos-with-the-worst-reputations/3/

[22] Retrieved 21 Apr. 2017 from https://hbr.org/2013/01/the-best-performing-ceos-in-the-world

[23] Retrieved 13 Jun. 2015 from http://www.mckinsey.com/insights/organization/the_ceos_role_in_leading_transformation 